\title{
PRESS FREEDOM AND ITS CHALLENGES IN THE NIGERIAN SOCIETY
}

\author{
Olomide, Kolawole \\ Department of Mass Communication, \\ Adeseun Ogundoyin Polytechnic, Eruwa, Nigeria. \\ kolaolomi@gmail.com
}

\begin{abstract}
The press is being seen as the $4^{\text {th }}$ arm of government and the eye of the people, hence the United Nations has always advocated for freedom for the press. Needless to say that a lot of countries of the world have been able to promote press freedom to an acceptable level. However, in 2019 Nigeria was among the Top 5 African Nations where the press are either being oppressed or threatened, with the most recent of AgbaJalingo of Cross River State. Consequently, Nigeria made the top 10 world countries with most threatened press freedom. The challenges of the press are numerous in Nigeria, hence, the need to underscore some of these challenges. The paper attempts to look at the press 'Act' from the lens of the United Nations and the legality of press freedom in Nigeria. The paper did a brief exposition of some of the issues facing the press generally, then dovetails into an $x$-ray of the challenges of the press in Nigeria. The paper concludes with prescriptive recommendations on what need to be done to help reduce the challenges of the press and enact proper press freedom in Nigeria.
\end{abstract}

Keyword: Press Freedom, Nigeria, Governance, Media Right. 


\title{
Introduction
}

\begin{abstract}
The United Nations has set aside $3^{\text {rd }}$ of May every year as press freedom day to signpost the importance of the media in global development (www.un.org/en/observances/press-freedom-day). This is quite useful especially for developing countries such as Nigeria that tend to underplay the crucial role of the media. Indeed, there is a positive link between development and freedom of the press as the advanced countries tend to have a higher level of press freedom. Development, as a concept, is a multifaceted idea. One of the issues involved in development is increased freedom freedom of the individual, freedom of groups and indeed freedom of the press. It seems that freedom of different kinds is an inalienable human right. Article 19 of the Universal Declaration of Human Rights (1948) prepared by the United Nations General Assembly in 1948 after the Second World War II states that:
\end{abstract}

"Everyone has the right to freedom of opinion and expression, this right includes freedom to hold opinion without interference and to seek, receive and impart information and ideas through any media, regardless of frontiers."

The above article empowers individuals, groups and professionals the freedom to express their views, opinions, and to disseminate information to the general public without fear or favour. This article comes after the deadly, devastating and catastrophe war that wrecked and damage not only political and economic sectors of the countries in the world, but also rob people of their innocent lives and properties. It is therefore imperative at this point in time to formulate laws and implement policies that will protect the rights of the people, one of which is the freedom of expression and right to entitlement of opinion.

With the landmark declaration of the United Nations, it is likely that many countries in the world would be encouraged to consider giving their peoples greater freedom and by extension, freedom of the press because individual freedom would be terribly constrained without freedom of the press. Undoubtedly, without press freedom, it would be difficult, if not practically impossible for individuals to "seek, receive and impart information and ideas" which the United Nations so passionately espouses. The Nigerian society being one of the countries under the United Nation has witnessed a lot of setback in this aspect, both during the military regime and even the democratic period. Hence, onus is placed on this paper to interrogate press freedom and its challenges in Nigeria.

\section{On the Concept of Press Freedom}

The meaning of press freedom is a complex concept as contrasted but related definitions have been offered by scholars. And as a result, it is difficult to arrive at a universally acceptable definition of press freedom. Nevertheless, some definitions of press freedom will be considered for the purpose of analysis.ApukeOberiri Destiny, quoting Sambe and Ikoni (2016:32), "press freedom focuses its attention on the unrestrained liberty to write or publish information for the consumption of the public". This definition according to Sambe and Ikoni is too broad and as such is difficult to conceptualize. The problem with the definition is that it gives absolute freedom or rights to journalists to write and publish information for public consumption. The implication with this is that it is possible for the 
press to be manipulated and use against the government for the benefit of some group of people or cabals that is after the fall of the government. The unlimited freedom accorded to the press is a problem. The unrestrained freedom of the press could also be used as a weapon to cause discord between the populace and the government, since information reaching the public are not checked.

Agee, Ault, and Emery's (1979:29) definition of the press freedom also encounters the same problem as Sambe and Ikoni's definition of press freedom. Agee, Ault, and Emerydefine press freedom as "freedom to print without prior restraint". In other words, the press is at liberty to send and print information to the public. The point here is that government should not interfere in the affairs of the press in letting the people to know and be aware of happenings - social, political and economic matters that concerns not only their state but also happenings round the world. However, the two definitions considered above most probably will give room for bias dissemination of information. The question is, from these definitions, how do we check the information of the press and curtail the press biases to give and disseminate accurate and transparent information to the populace for consumption? The answer to this question is not provided in the definitions considered. Press freedom is the complete freedom to disseminate and print of information that is not detrimental, bias and influence to cause chaos, conflict, crises or violent in the country. This presupposes that the press can be compromised and used to achieve a set desire of some group of people as against the general welfare of the people. Akeem AyofeAkinwale (2010:50) argues similarly that press organizations may also be deployed to protect elite interests to the detriment of the larger society. Nevertheless, the importance of press freedom cannot be overemphasized as it is seen as the bedrock of democracy and good governance. A good government, it is scholarly argued, cannot strives in a situation where the press is censored and constraint or influence to act in the interest of the elite class. Consequently, press freedom is tantamount to the recognition of individual's rights, supremacy of the constitution and participation of the populace in political affairs.

Consequently, the development and growth of a society is dependent partially in the entrenchment of the rights and freedom of the press. As such, the freedom of press has gone beyond writing and publishing of information for public consumption. It is now seen as the $4^{\text {th }}$ arm of government and the eye of the citizen. The press has become a machinery through which government policies and formulations are questioned and interrogated. The press has developed so wide that they also engage in investigation; some call this investigative journalism. One would likely recollect that rumor has it that the death of Dele Giwa in Nigeria through a letter bomb was due to his investigating journalism. It must be noted that most issues that arises from press freedom restriction or assault on press men is not just based on writing and publishing stories, but it most times deals with publishing things that have been investigated and detrimental to people in government. Howbeit, it must be noted that for every freedom, there are always limitations, hence the need to critically look at the legal frame work that supports press freedom.

\section{Legal Basis of the Right to the Freedom of the Press}

Section 22 of the 1999 constitution of the Federal Republic of Nigeria states that under the fundamental objectives and directive principles of state policy, the press has a duty conferred on it thus: "the Press, Radio, Television and other agencies of the mass media shall at all times be free to uphold the fundamental objectives contained in this Chapter and uphold 
the responsibility and accountability of the Government to the people."Also in section 39 it state that in order to enable the press carry out this constitutional obligation, the Constitution provides for the freedom of expression including freedom to hold opinions and to receive and impart ideas and information without interference of any sort.The provisions of Chapter 2 of the Constitution under which we have Section 22 is not justiciable as journalists or lawyers cannot cite any provisions of that chapter as a defence in litigations on matters pertaining to publications or broadcast. Section 22 undoubtedly gives the press the responsibility of holding the government accountable to the people. However, (Ifeyinwa and Chinelo 2011) asserts that it neither empowers nor protects the media to discharge its duty. Howbeit, the constitutional provision for the freedom of the press is limited under the law. The constitution in section 45 allows for derogation from the freedom in the interest of defence, public safety and order, public morality or public health or for the purpose of protecting the rights and freedom of other persons.

More so, Section 19 of the United Nations' Universal Declaration of Human Rights (UDHR) provides that "Everyone has the right to freedom of opinion and expression; this right includes freedom to hold opinions without interference and to seek, receive and impart information and ideas through any media and regardless of frontiers" Also, in determining the extent of a person's right to freedom of expression, (Ademola, 2015) in the case of Director of Public Prosecution v Obi stated that:

A person has every right to discuss any grievance or criticise, canvass and censor the act of government and their public policy. He may even do this with a view to effecting a change to the party in power or to call attention to some of the weaknesses of the government so long as he keeps within the limits of fair criticism. It is clearly legitimate and constitutional, by means of fair argument, to criticise the government of the day. What is not allowed is to criticise the government in a malignant manner as described in this case. For such attacks, by their nature, tend to affect the public peace.

The United Nations Convention against Corruption (adopted by Resolution 58/4 of the General Assembly of the United Nations in October 2003) requires governments to ensure citizen participation in anti-corruption measures through: (a) enhancing the transparency of and promoting the contribution of the public to decision-making processes; and (b) ensuring that the public has effective access to information.

The right to freedom of expression is explained under the African Charter on Human and People's Rights thus: "Every individual shall have the right to receive information as well as the right to disseminate opinion within the law." The implication is that it recognizes a law that is not infringed upon by any domestic law. In the case of Media Rights Agenda and Others v. Nigeria, the Commission of the ACPHR said that the right what be limited in accordance with law should be understood to require such limitations to be done in term of domestic legal provisions which comply with international human rights standard. The developmental function and roles of the media include gathering and dissemination of information, verification of news, education and enlightenment of the people, shaping of public opinion, setting of national agenda, safeguarding of right of individuals, interests, 
groups, advertisement of goods and services etc. saddled with this responsibility, the media cannot function effectively without proper legal backing.

Generally, it is believed that press freedom cannot strive during the military regime and that it is only democratic setting that can house the freedom of the press essentially. while Nigeria has faced a lot of assaults on press men and restriction of press freedom during the military regime, it will be of no use to begin the trajectory of crises and challenges of the press in Nigeria, but then, it will be worthwhile for the benefit of this research to look into environment and circumstances that fosters press freedom, it is on this basis that we can start our interrogation to know if the Nigerian democratic society of today have such environment.

\section{Environments for Manifesting Freedom of the Press}

For any nation's press to be truly free there must be the right mix of the legal, political and economic environments. A deficiency of any of these setting will impinge the total and true freedom of the press. The cornerstone for a free press and a free society is possible when the right laws are in place in a suitable environment with assured political stability. Therefore, the interplay of these environments guarantees actual freedom of the press. The legal environment encompasses an examination of both the laws and regulations that could influence media content and the government's inclination to use these laws and legal institutions to restrict the media's ability to operate. Under political environment, Nigeria has one of the most vibrant and varied media landscapes in Africa, and the print sector in particular is generally outspoken in its criticism of unpopular government policies. However, the media sometimes face politicised interference from public officials and regulators over their criticism of the government or coverage of sensitive issues, such as high-level corruption and national security. Economic environment includes the structure of media ownership; transparency and concentration of ownership; cost of establishing and running a viable press. The press repression in Nigeria aside having some legal encumbrances has to some extent political hinges. Due to political instability, the press has considerably suffered harassment from the police, military and thugs that were politically motivated.

One might think that the Nigerian society should proffer a proper enabling environment for the press, but between January and September 2019, the Nigerian Society has already witnessed 61 attack on the press and the worst since the dawn of democracy, The regime of the president;MuhammadBuhari has witnessed the highest attack on press men since the dawn of democracy in Nigeria. This record was published on premium times by the coalition for whistle blowers protection and press freedom. Day by day, the Nigerian environment has not been giving proper expression to the press. Having established this fact, it becomes needful to look at the challenges of press freedom generally.

\section{General Challenges of Press Freedom}

Press Freedom is often controversial. Part of the reason is that people in government often do not want a powerful press that could be a counterpoise to their exalted position. They would rather that the press be sycophantic so that their shortcomings are not brought to the public glare. Despite the skepticism of many persons in power towards the press, it is obvious that the power of the media cannot be easily wished away. It was in this context, that a former American President Thomas Jefferson declared that if he had a choice, he would prefer media without government than government without the media. Such a strong 
endorsement coming from the Presidency of America, often considered the world's strongest democracy, is worth noting, and perhaps, worth celebrating.

As Sambe and Ikoni (2004:11) have pointed out, there are six issues which press freedom is all about.

a. No prior or subsequent restraint

b. Freedom to gather information

c. The right not to be compelled to disclose the source of information

d. Freedom of impart

e. The right to receive information

f. Freedom from unreasonable punishment for what is published.

Indeed, the above issues reasonably represent what press freedom is all about. It even goes beyond to articulate the fact that political authorities should not make unreasonable laws to gag the press. As Nwanne (200:126) has previously noted:

It is essential that political authorities in any given environment must have the sagacity and maturity to appreciate that a free and unfettered press is more likely to pursue the goals of national development than a docile one. Quite often, the perceived security of the incumbent regime is interpreted in a way and manner that might suggest that the press constitutes a 'security risk' through the kind of stories it publishes about those in power and their families. Any publication that does not sing the praises of those in power to high heavens is perceived as 'sedition', 'treason' and similar other adjectives.

The link between good governance and a vibrant press cannot be doubted. As Asekome (2008:279) has stated: The greatest sources of information in any nation are the mass media, which include the press, the electronic, and of course the Internet. It is through the mass media that information is disseminated which is expected to influence both the government and the governed, shapen public opinion that consequently brings about sound policy formulation, result-oriented reforms and positive changes.

As previously noted, there is a positive correlation between good governance and an effective media institution. That was the point eloquently articulated by a former American President, Jefferson, previously referred to. It must be noted that the major challenge with the press can be summed up to as the tussle with the government. The press really does not have much issue with the ordinary citizens of any nation rather; the press and the government are always at loggerhead. Having examined this, it is needed to snowball into the challenges of press freedom in Nigeria. 


\section{The Challenges of Press Freedom in Nigeria}

Nigeria emerged from colonialism in 1960. While colonized, Nigerians suffered press freedom infractions from the colonial authorities. According to Momoh (2002:10) restrictive media laws could be said to have actually taken roots in 1903 with the enactment of Newspaper Ordinance of that year and the sedition Ordinance of 1909. As Momoh recalled, perhaps the most notorious press gag law was the 1917 Act. The author noted that "it brought together previous colonial laws". No doubt, these laws were put in place to curb the perceived "excesses" of the local press and sufficiently frighten them to desist from attacking the Colonial Administration. Tellingly, most of those Draconian laws have remained in Nigeria's law books because the new rulers who took over from the colonialists were not interested in abrogating them. Not unexpectedly, therefore, in 1964, this earlier Act was amended and has been the basis of anti-press laws in Nigeria. The first civilian administration under TafawaBalewa, the Prime Minister enacted the law. If the civilian administration was not particularly media-friendly, it was even worse with the subsequent military administrations, each of them trying to outdo each other in an effort to put the media in its "rightful place".

In the United States of America, there is a stable democracy, anchored on freedom of the individual and the press. The first amendment to the American Constitution states inter alia that "Congress shall make no laws abridging the freedom of the press". But in Nigeria, the writers of the constitution did not seem convinced that Nigerians deserved unconditional freedom, hence the frequent reasons to the word 'provided'. Such punctuation or vitiation of the freedom of the press in Nigeria often provides opportunity for those in authority to take advantage.

There are a lot of factors in Nigeria that have militated against press freedom. According to Momoh(2002, p.10) restrictive media laws could be said to have actually taken roots in 1903 with theenactment of Newspaper Ordinance of that year and the sedition Ordinance of 1909. As Momoh recalled, perhaps the most notorious press gag law was the 1917 Act. Against this backdrop, this research discusses some factors militating against press freedom asoutline by Asemah (2011) as follows:

Legal Pressure: Even though press freedom is granted in the constitution, there is no statutorybackup in Nigeria. Journalist do not enjoy press freedom as the constitution counteract each other for instance section 39 of the 1999 Nigerian constitution qualifies and tactically curtails freedom of expression and of the press. Subsection two of section 39 places prior restraint on the ownership of the media for the exercise of freedom of speech particularly on the broadcast media. Chigbo (2007) observes that section 39 subsections 3 validates and justifies any law made for the purpose of preventing disclosure of information received in strict confidence while in the service of the state in government. Section 45 of the constitution further limits the exercise of freedom of expression and the press. "This shows that even though press freedom is guaranteed in theconstitution of Nigeria, it is only a mere say as there are techniques used by government in Nigeriato dodge what has been guaranteed in the constitution".

Economic And Political Pressure: The economic and political pressure in Nigeria makes somenewspapers or radio station most especially government owned to publish things in support of the government by so doing the definition of press freedom is defeated. In fact, it 
can be said In Nigeria that the government owned media station automatically becomes the machinery of the government in position of authority, to pass the information that glorifies the government and cast aspersion on the credibility of the opposition. The government owned station becomes the mouthpiece of the government in authority and most times objectivity is lacking in their media report. Example is the Nigerian Television Authority (NTA). In recent years, the Nigerian government has also either sack, victimize, or transfer out media personnel working in the government owned media agencies who are not in support of them or are every trying to be objective in their report and by implication, there objectivity showcasing the lapses of the government in position. Another issue under this heading is the issue relating to some private media station in Nigeria who are either owned by politician or those in support of some political ideology or sect. I once had a personal experience trying to publish a story in one of the Nigerian media Outlet, but was denied because the media head claim that such story will be against the political standing and integrity of the owner of the outlet. So as much as this issue happens with government owned media station, it also happens in private owned media station.

Secrecy: Secrecy in Nigeria limits the right of the people to know, by hindering the press fromhaving access to government sources and records. We have government agencies or officialsevading journalist so that they cannot get information about government activities. In June 2020, the Government of Ebonyi State bound some media personnel for life from covering the events in the state house, also, we have also witnessed some government both at state level and national level in Nigeria placing ban on certain media outlet or personnel, unjustly seizing of media license like that which was done to African Independent Television (AIT) in 2020 among others. All this are difficult situations being faced by the media in Nigeria. most journalist in Nigeria sometimes have to go through risking their life's to be able to expose the evil plot of some government personnel to the public, while a lot of them get threat to kill the story. The Nigeria government is not open enough to the media.

Direct Censorship and Force: The government uses forces, violence and harassment to restrict Press freedom. There are many instances when Journalist were physically brutalized in an event to cover a report. We have instance of Dele Giwa who was killed via a letter bomb because he was expressing his view on public issues. Even as at $9^{\text {th }}$ of September 2020, the Punch New Paper in Nigeria reported case of assault and arrest of peaceful protesters and men of the press who were covering the protest against the hike in electricity and fuel tariff recently implemented by the government of Nigeria in Lagos state. Also, AgbaJalingo a media Journalist in Cross River State of Nigeria was among the top 10 world journalist on threat list in 2019, not to shy from the recent issue that transpired between a Journalist and the Nigeria Former Minister of Aviation; Femi Fani-Kayode who publicly Insulted the Journalist just to mention a few. This and many more are what is been faced by the press in Nigeria.

Too Many Media Houses and Poor Remuneration: Although, a lot of people might want to consider too many media houses in Nigeria as a plus and a good thing for the nation, considering the wide expanse of land and the population of the country, however, this is turning more to a disaster for the nation. Due to the too many media houses, it makes journalism in Nigeria porous and reduces the value of true journalism. Journalism has now become a business venture that the rich invest their money. Objectivity is losing out in the business. And due to so many media houses around, journalist moves from one media station to another for higher pay, it is now the case of the highest bidder. The passion for true 
journalism is dying gradually. another thing to note is that most media houses pay poor remuneration to their staffs, In fact, some even pay commission based on the advert you are able to bring to the media outlet, this in no wise frustrate the activities of journalist and put them under the pressure of doing anything just to survive. This is a bad omen in the Nigerian media.

Fake News and Social Media: The use of social media in this age is also serving as issue to journalism in Nigeria, because so many fake news are been circulated through the social media platforms. Needless to say that Nigeria has not been able to develop the capacity to sensor out fake news and reports from circulating across the social media. Every day, Nigerians are confronted with trying to discern which news is authentic, coupled with the fact that they are still concerned with knowing to what extent of the truthfulness of this so called authentic news. So the social media and several fake news have been a major challenge to the media in Nigeria.Having examined the challenges facing the media in Nigeria, it is important to conclude with the reason why the press needs to have freedom in Nigeria.

\section{Reasons for Press Freedom and Recommendations}

Many wrongly believe that press freedom is all about introverted freedom of journalists to print or air whatever pleases them. But that is not so the real situation is that journalist is professionals saddled with the responsibility of gathering, analyzing and presenting of news of the day to the people. Therefore Journalists require commendation and a bit of respect. Given this much responsibility, Oji (2006:424) makes clear argument on the need for freedom of the press. He postulated that the press requires freedom for the following reasons. That the media must have constitutional safeguards to enhance the discharge of its duties. That the media must have access to information. That the media should be protected to protect and prevent the disclosure of sources of information. Call for the stipulation of freedom of the press in the text of nations' constitutions and that it should be proceeded by a statement of the obligation of the press. Where there are sedition laws in the world, clauses which do not see truth as a condition for the free practice of journalism should be expunged; In places where the constitution or any act cedes the power to grant a media license to any government official, such as Section 39 of the 1999 constitution and replicated in the National Broadcasting Commission Decree of 1992, should be expunged.

Since press freedom is granted in the constitution of Nigeria, there should be statutory backup in. Journalist should be allowed to enjoy press freedom. In order not to hinder press freedom, journalist in Nigeria should be allowed to have access to government sources and records as long as it will not bring chaos to the society at large.

\section{Conclusion}

From the foregoing, it has been affirmed that although press freedom is a major concern during non- democratic regime, but then Nigeria unlike some other democratic State has not been able to out grown media suppression and oppression even in the democratic setting, hence the paper examined some of the challenges facing the media in Nigeria and conclude by recommending what needed to be done in a bid to help reduce some of the challenges being faced by the media in Nigeria. 


\section{References}

Agee, W. K. Ault, P. H. Emery, E. (1979). Introduction to Mass Communications. (6th ed). New

Ajibade, O. (2003). "Press Freedom and the Social Political Obligations of the Mass Media in Nigeria". In G. J. Afolabi,(Ed). Babcock Journal of Management and Social Sciences.

Akinwale, A. A. (2010). "Repression of Press Freedom in Nigerian Democratic Dispensations." African Development. 35(3). 47-70.

Apuke, D. O. (2016). "Exploring the Factors Affecting Press Freedom in Nigeria." Higher Education of Social Science. 11(2). 32-34

Asekome, M. O. (2008). 'Role of the Press in Nigerian Economic Reforms and Democratization Process for National Development" In F. I. A. Omu and G. E. Oboh (Eds). Mass Media in Nigerian Democracy. Ibadan: StirlingHorden Publishers.

Asemah (2011) Selected Mass Media Themes. Jos: Great Future Press.

Baran, S. and Dàvis, D.K. (2003) Mass Communication Theories. New York: McGraw Hill.

Baran, S. J. (2002). Introduction to Mass Communication: Media Literacy and Culture. (2nd ed). Boston: McGraw-Hill Higher Education.

Chigbo, R. (2007). Mass Media in Nigeria: Perspective on growth and Development. Makurdi: Aboki Publishers.

Folarin, B. (2002). Theories of Mass Communication. Abeokuta: Link Publications.

http://www.africaunion.org/official_documents/Treaties_\%20Conventions_\%20Protocols/Ba njul\%20Charter.pdf. Article 9 of the ACHPR 1982. Accessed 20 August 2020.

Ifeyinwa, N. \&Chinelo, U. A. (2011). "Freedom of the Press in the Eyes of the Nigerian Law" Being a paper delivered at the 4th international conference on information law (ICIL) in Thessaloniki city, Greece.

Igwe, S. C. (2010). How Africa Underdeveloped Africa. Port Harcourt. Professional Printers and Publishers.

Momoh, T. (2002). Nigerian Media Laws. Lagos: Efua Media Associates.

Nwanne, B. U. (2008). Essentials of News Reporting and Writing. Lagos: Broada Publications.

Nwanne, B. U. (2012). "The Mass Media and Development Communication: Emerging Issues in Nigeria" In O. D. Awaritefe and C. Ewhrudjakpor (Eds). Journal of Social and Management Sciences.7 (1). 
Oji, M. (2006). "Comparative Media Systems: A Global View of Press Freedom". International Journal of Communication. N. Okoro (Ed). No. 6.

Radio Nigeria (2014). Effective Implementation of Freedom of Information Act (Commentary). February 24.

Sambe, J. A. and Ikoni, U. D. (2004). Mass Media and Ethics in Nigeria. Ibadan: Caltop Publications Nigeria Ltd.

Sunday Sun, (2014). “Media Clampdown: NPAN Seeks End to Siege”. June 8, p.3.

The Constitution of the Federal Republic of Nigeria 1999

Ufuophu-Biri, E. (2006). "Post-Mortem of the Nigerian Press Freedom under Military Rule". In N. Okoro (Ed). International Journal of Communication. Number 4, June.

United Nations' General Assembly Resolution 217 (III) A of 1948

Universal Declaration of Human Rights. (1948). Article 19.

Vanguard (2014). "Nigerian Press Organisation (NPO). Crackdown on the Media: Our Stands." Vanguard Newspaper.June 13. p.2.

Vanguard, (2013). "FG Withdraws Felony Charges Against Leadership Reporters". Vanguard Newspaper. May 3. p. 15.

York: Harper and Row. 